\title{
Bariatrik cerrahi sonrası akut dönem vücut kompozisyon değişimlerinin cinsiyet ve anatomik bölgeye göre değerlendirilmesi
}

\author{
Evaluation of body composition changes after bariatric surgery according to gender \\ and anatomical region
}

Mustafa Atabey, Muhammed Raşid Aykota, Sevda Yılmaz

Gönderilme tarihi: 26.05 .2020

Kabul tarihi: 29.06 .2020

Özet

Amaç: Bariatrik cerrahi (BC) akut kilo kaybına neden olur, ancak vücut kompozisyonundaki postoperatif erken dönem değişiklikler üzerindeki etkisi hakkında yeterli bilgi yoktur. Bu çalışmada, Mini gastrik bypas (MGB) ve Sleeve gastrektomi (SG) sonrası ilk aydaki vücut kompozisyon değişiklikleri cinsiyet ve anatomik bölgeye göre incelenmiştir.

Gereç ve yöntem: MGB ve SG öncesi ve postoperatif 1 ay sonra 100 morbid obez hastada (70 kadın, 30 erkek) vücut kompozisyonu (üst ekstremite, alt ekstremite, gövde kas ve yağ oranları) ayrıca tüm vücut yağ doku ve yağsız doku kütlesi Biyoelektrik Empedans Analizi (BIA) teknolojisi kullanılarak ölçüldü.

Bulgular: MGB sonrası kadın ve erkeklerde hem tüm vücut yağ kütlesinde $(p=0,071)$ hem de yağsız doku kütlesinde $(p=0,781)$ azalma gerçekleşmiştir. Ayrıca MGB sonrası tüm gruplarda kas kütle kaybı istatistiksel olarak anlamlı değildir. Ancak SG sonrası kadınlarda anlamlı yağ doku kaybı oluşurken $(p=0,014)$ erkeklerde yağsız doku kütlesinde $(p=0,029)$ ve üst ekstremite kas kütlesinde $(p=0,001)$ anlamlı azalma tespit edilmiştir.

Sonuç: Çalışmamız bariatrik cerrahinin akut kilo kaybına neden olduğunu ve hem tüm vücut yağ kütlesi hem de yağsız doku kütlesinin etkilendiğini ve bazı anatomik bölgelerde kas kaybının yağ kaybından daha yüksek olduğunu açıkça göstermektedir. Bariatrik cerrahi sonrası akut dönemde vücut kompozisyonundaki değişimlerin cinsiyet ve yapılan cerrahi prosedüre göre farklılıklar içerebileceği bulunmuştur. Kas kütle kaybının uzun vadede zararlı sonuçları olabileceğinden, bariatrik cerrahi sonrası beslenme stratejilerinin mümkün olan en kısa sürede belirlenmesi gerekmektedir.

Anahtar kelimeler: Mini gastrik bypas, sleeve gastrektomi, vücut kompozisyonu, yağ doku kütlesi, yağsız doku kütlesi.

Atabey M, Aykota MR, Yılmaz S. Bariatrik cerrahi sonrası akut dönem vücut kompozisyon değişimlerinin cinsiyet ve anatomik bölgeye göre değerlendirilmesi. Pam Tıp Derg 2020;13:665-675.

\begin{abstract}
Abstrat
Purpose: Bariatric surgery induces acute weight loss, but there is insufficient information about its effect on postoperative early changes in body composition (BC). In this study, BC changes in the first month after Mini gastric bypass (MGB) and Sleeve gastrectomy (SG) were examined according to gender and anatomical region. Materials and methods: Body composition changes in 100 morbidly obese patients (70 women, 30 men) after MGB and SG were measured using Bioelectrical Impedance Analysis (BIA) technology.

Results: After MGB, both men and women had a reduction in both their body fat $(p=0.071)$ and lean tissue mass $(p=0.781)$. In addition, muscle mass loss was not statistically significant in all groups after MGB. However, after SG, significant fat tissue loss occurred in women $(p=0.014)$, whereas in men, there was a significant decrease in lean tissue mass $(p=0.029)$ and upper limb muscle mass $(p=0.001)$.

Conclusion: Our study clearly shows that bariatric surgery induces acute weight loss and that both whole-body fat and lean tissue mass are affected, and muscle loss in some anatomical regions is higher than fat loss. It has been found that changes in body composition in the early period after bariatric surgery may include differences according to gender and surgical procedure. Since muscle mass loss can have harmful consequences in the long term, nutritional strategies should be determined as soon as possible after bariatric surgery.
\end{abstract}

Key words: Mini gastric bypass, sleeve gastrectomy, body composition, fat mass, lean tissue mass

Atabey M, Aykota MR, Yilmaz S. Evaluation of body composition changes after bariatric surgery according to gender and anatomical region. Pam Med J 2020;13:665-675.

Mustafa Atabey, Dr. Öğr. Üye. Biruni Üniversitesi Tıp Fakültesi Genel Cerrahi Anabilim Dalı, İstanbul, Türkiye, e-posta: atabey21@gmail.com (orcid.org/0000-0002-9226-4358)

Muhammed Raşid Aykota, Dr. Öğr. Üye. Pamukkale Üniversitesi Genel Cerrahi Anabilim Dalı, Denizli, Türkiye, e-posta: muhammedaykota@ hotmail.com (orcid.org/0000-0003-1862-6186) (Sorumlu Yazar)

Sevda Yılmaz, Dr. Öğr. Üye. Pamukkale Üniversitesi Genel Cerrahi Anabilim Dalı, Denizli, Türkiye, e-posta: syilmaz_md@hotmail.com (orcid. org/0000-0002-1309-0805) 


\section{Giriş}

Obezite, hem çocukluk hem de erişkinlik çağında cinsiyet ayrımı yapmaksızın insanları etkileyen ulusal bir salgın haline gelmiştir [1]. Obezite prevalansı 2017-2018'de \%42,4 idi. 1999-2000'den 2017-2018'e kadar, yetişkinlerde hem obezite hem de ciddi obezite prevalansı artmıştır [2]. Obezitenin ayrıca hipertansiyon, uyku apnesi, diyabet ve hatta kanser gibi birçok hastalık ile ilişkili olduğu bilinmektedir. Sonuç olarak, obezite önlenebilir ölümlerin önde gelen nedenlerinden biridir. Özellikle morbid obezite için, bariatrik cerrahi kanıtlanmış tek etkili ve sürdürülebilir tedavi seçeneğidir [3]. En sık uygulanan bariatrik cerrahi prosedürlerinden Roux-en-Y gastrik bypass (RYGB) ve sleeve gastrektomi (SG) ve mini-gastrik bypass (MGB) sonuçları daha öne çok kez karşılaştırılmıştır. Kilo kaybı ve komorbiditelerin iyileşmesi açısından hangi cerrahi tekniğin daha üstün olduğuna dair fazla kanıt yoktur [4]. Ayrıca, bariatrik cerrahi yöntemlerinin konvansiyonel tedavi yöntemlerine göre daha uzun süreli sağkalım sağladığı gösterilmiştir [5]. Son yıllarda sleeve gastrektomi, etkin kilo kaybı sağlaması, düşük komplikasyon riskleri ve kolay uygulanabilir olması nedeniyle tüm dünyada sıklıkla uygulanan bariatrik cerrahi prosedür haline gelmiştir [6, 7]. RYGB yöntemi daha fazla invaziv olmasına rağmen, SG ve MGB prosedürlerine göre daha etkin klinik sonuçlar elde edilmiştir [8]. Bununla birlikte, bu üç prosedürün obezite ile ilişkili komorbiditeler üzerine etkinliğini ve yönetimini karşılaştıran randomize kontrollü klinik çalışmalar yoktur [9]. Tüm avantajlarına rağmen, bariatrik cerrahinin komplikasyonları vardır; bunlar hem hastaya hem de yapılan cerrahi prosedüre bağlı olabilir [10]. Aslında, bariatrik cerrahi prosedürleri arasında sağkalım faydaları ve azalmış mortalite oranları açısından hiçbiri "ideal" bir seçenek değildir [11]. Mini-gastrik bypass olarak tanımlanan yeni gastric bypass prosedürleri geliştirilmiştir. Teknik olarak daha basit olması, daha kısa ameliyat süresi ve daha az sayıda anastomoz ve düşük kaçak riski gibi bazı avantajlara ek olarak, bu teknik etkin kilo kaybı sağlar ayrıca morbidite ve mortalite oranlarında önemli bir azalmaya yol açar $[12,13]$.

Morbid obezite (Sınıf III obezite), vücut kitle indeksinin (VKI) $40 \mathrm{~kg} / \mathrm{m}^{2}$ üzerinde olmasıdır ve dünyada 25 ila 40 yaş arasında obez olmayanlara kıyasla en yüksek mortalite oranına sahip hastalıklardan biri olarak kabul edilir [14]. Günümüzde bariatrik cerrahi prosedürleri, sınıf III obeziteyi kontrol etmenin en etkili yolu olarak kabul edilmektedir. BC faydaları, uzun süreli kilo kaybı, aşırı kiloya bağlı yandaş hastalıklardan kurtulma, yaşam kalitesinde iyileşme ve sağlık hizmetlerinin maliyetini düşürmesidir [15]. VKI obezite şiddetini sınıflandırmak ve cerrahi etkinliği değerlendirmek için yararlı bir indekstir, fakat bu indeks tüm vücut yağ kütlesi (FM, fatt mass) ve yağsız doku kütlesindeki (LTM, lean tissue mass) değişiklikleri yansıtmaz [16]. Bariatrik cerrahi sonrası erken dönemde vücut kompozisyon değişiklilkleri üzerine yapılmış çalışmalar genellikle postoperatif 1. yıldan sonra yapılmıştır. Kilo veriminin hızlı olduğu ve vücut kompozisyonlarındaki değişikliklerin fazla olduğu postoperatif 1 . ayda yapılmış çok fazla çalışma yoktur [17]. SG ve RYGB sonrası 1. ayda FM ve LTM değişikliklerini gösteren çalışmalar vardır [18, 19]. MGB ve LSG'nin vücut kompozisyonu değişiklikleri üzerindeki akut etkileri, postoperatif tıbbi bakımı iyileştirmeye yardımcı olabilir ve FM ve LTM deki değişikliklere göre yeni stratejilere ilham verebilir.

Bu çalışmanın amacı, MGB ve SG'den bir ay sonra vücut kompozisyonu değişikliklerini cinsiyet ve anatomik bölgeye göre (üst ekstremite, alt ekstremite ve gövde) yağ ve kas dağılımlarını belirlemek ayrıca her iki cerrahi prosedürün 1. ay \% EWL (Excess Weight Loss) ve VKİ değişimlerini kıyaslamaktır.

\section{Gereç ve yöntem}

Çalışma retrospektif olarak kayıtların taranmasıylaeldeedilen verilerden planlanmıştır. İki ayrı merkezde gerçekleştirilen SG ve MGB operasyonları çalışmaya dahil edildi. Çalışmayı yürütmek için Pamukkale Üniversitesi Tıp Fakültesi Girişimsel Olmayan Klinik Araştırmalar Etik Kurulu'ndan onay alındı. Çalışma Dünya Tıp Birliği Helsinki Deklarasyonu'na uygun olarak gerçekleştirildi. Bu retrospektif çalışmada, Haziran 2014 ile Ekim 2019 arasında iki cerrah iki farklı hastanede gerçekleştirilen SG $(n=50)$ ve MGB $(n=50)$ uygulanan 20 ila 72 yaş $(38,82$ $(S S=11,77)$ ) arası toplam 100 hasta (70 kadın, 30 erkek) değerlendirildi. VKI $\geq 40 \mathrm{~kg} / \mathrm{m}^{2}$ veya VKI $\geq 35 \mathrm{~kg} / \mathrm{m}^{2}$ ve kardiyovasküler hastalık, hipertansiyon, uyku apne sendromu veya tip 2 diyabet gibi en az bir ciddi komorbiditesi olan 
hastalar operasyon kriteri olarak belirlendi. Tüm hastalar preoperatif ve postoperatif 1. ayda aynı kurumda değerlendirildi. Bu takip süresi boyunca her hastaya aynı beslenme uzmanı tarafından benzer beslenme diyetleri ve fiziksel aktiviteler önerildi.

\section{Preoperatif değerlendirme}

Bağımsız değişkenler yaş, cinsiyet, başlangıç ağırlığı ve VKİ, vücut kompozisyonu [üst ekstremite, alt ekstremite, gövde kas kütlesi $(\mathrm{kg})$ ve yağ kütlesi $(\mathrm{kg})$ ] vücut kompozisyonu analizörü Tanita BC-418 ve MC-580 (Tanita Corp., Tokyo, Japonya) ile ameliyat öncesi ölçüldü. Aynı ölçümler ameliyat sonrası 1. ayda tekrar yapıldı. Diabetes mellitus (DM), hipertansiyon (HT), hipotiroidizm, uyku apnesi, hiperlipidemi gibi komorbiditeler değerlendirildi.

Kilo kaybı sonuçları, aşırı kilo kaybının yüzdesi (\% EWL) ve VKl'daki değişiklikler olarak kaydedildi. VKI: $\mathrm{kg} / \mathrm{m}^{2}$ olarak hesaplandı. \% EWL şu şekilde hesaplandı: [(preoperatif kilo (kg)-güncel kilo (kg))/preoperatif kilo (kg)-ideal kilo(kg))] *100

İdeal kilo Devine formülüne göre kadınlarda ve erkeklerde ayrı ayrı hesaplandı.

\section{Cerrahi teknik}

MGB uygulanan tüm hastalar için 15-18 cm uzunluğunda gastrik poş oluşturuldu ve Treitz ligamentinden 100-280 cm uzakta yanyana (45 mm) loop gastrojejunostomi yapıldı. Biliopankreatik barsak uzunluğu hastanın yaş ve preoperatif VKI'ne göre ayarlandı. Mide poşunun arka duvarına longitudinal gastrojejunostomi yapıldı ve enterostomi açıklığı 2,0 polydioxanone (PDS) ile kapatıldı.

SG ameliyatları tek cerrah tarafından tek merkezde gerçekliştirildi. Genel anestezi altında French pozisyonunda ameliyata başlandı. Optik trokar ile batın içine girildi. Karaciğer sol lobu Nathanson ekartör yardımı ile eleve edildi. Toplamda 6 trokar kullanıldı. Gastrokolik ligaman mide büyük kurvaturundan his açısında kadar Ligasure $5 \mathrm{~mm}$ (Covidien, Mans-field, MA) ile diseke edildi. Anestezist tarafından 38-Fr gastric kalibrasyon tüpü orogastrik yoldan yerleştirildi. Pilordan yaklaşık $3 \mathrm{~cm}$ mesafenden ilk stapler yerleştirildi. Mide antrum kısmında laparoscopic Endo GIA ultra stapler (Covidien) siyah kartuş (60mm Tri-Staple) kullanılarak transekte edildi. Midenin geri kalan kısımları doku kalınlığına göre stapler ayarlaması yapılarak rezeksiyon tamamlandı. Sonrasında tüm stapler hattı 3,0 V-Loc sütür (Covidien) ile kanama ve kaçak kontrolü için inverte edilerek kapatıldı. Metilen mavisi ile intraoperatif kaçak testi yapıldı. Rutin olarak dren kullanılmadı. Postoperatif 1. günde skopi eşliğinde kaçak testi yapıldıktan sonra sıvı gıda ile oral alıma başlandı. Taburculuk sonrası iki hafta düşük molekül ağırlıklı heparin subkutan devam edildi.

\section{Postoperatif değerlendirme}

Tüm hastalara taburculuk sonrası reçete edilen mide koruyucu ve safra taşı oluşumu önleyici ilaç, günlük multivitamin ve mineral takviyesi de dahil olmak üzere rutin öneri protokolleri uygulandı. Hastalara 1, 3, 6, 9 ve 12. aylarda takip önerildi. Bu kontrollerde vücut kompozisyonu analizörü ile ölçümleri yapıldı.

\section{Statistical analysis}

İstatistiksel analiz için SPSS 25.0 (SPSS, Chicago, IL, ABD) programı kullanılmıştır. Sürekli değişkenler için ortalama \pm standart sapma, kategorik değişkenler için sayı ve yüzde değerlerinin çıkarılmasında betimsel istatistikler kullanılmıştır. Ayrıca ameliyat türleri ile vücut kompozisyonlarının karşılaştırılmasında ise Mann Whitney $U$ testi kullanılmıştır. İstatistiksel anlamlılık için $p<0,05$ olarak kabul edilmiştir.

\section{Bulgular}

Tablo 1'de çalışmaya katılan 100 (50 hasta MGB, 50 hasta SG) hastanın (kadın $\% 70 n=70$, erkek \%30 n=30) preoperatif sosyodemografik dağılımları yer almaktadır. Hastaların genel yaş ortalaması 38,82 ( $S S=11,77)$, genel boy ortalaması $164,55(S S=10,58) \mathrm{cm}$, genel kilo ortalamaları ise 124,18 (SS=24,4) $\mathrm{kg}$ ve genel VKİ ortalaması 54,20 (SS=59,20) kg/m² olduğu belirlenmiştir.

Tablo 2'de görüldüğü gibi $M G B$ ve SG sonrası 1. ay \% EWL (Excess Weight Loss, fazla kilo kaybı yüzdesi) değerleri karşılaştırılmıştır. $M G B$ ve SG 1. ay \% EWL değerleri arasında istatistiksel anlamlı bir farklılık saptanmamıştır $(p=0,940)$. 
Tablo 1. Hastalara ait preoperatif sosyodemografik bilgiler

\begin{tabular}{lll}
\hline Değişken (Kategorik) & $\mathbf{n}$ & $\%$ \\
\hline Ameliyat Türü & & \\
MGB & 50 & 50,0 \\
SG & 50 & 50,0 \\
Toplam & 100 & 100,0 \\
Cinsiyet & & \\
Kadın & 70 & 70,0 \\
Erkek & 30 & 30,0 \\
Toplam & 100 & 100,0 \\
Değişken (Sayısal) & Ortalama & Standart Sapma \\
Yaş & 38,82 & 11,77 \\
Boy & 164,55 & 10,58 \\
Kilo & 124,18 & 24,84 \\
VKI & 54,20 & 59,20 \\
\hline
\end{tabular}

Tablo 2. MGB ve SG 1. ay \% EWL karşılaştırması

\begin{tabular}{llll}
\hline & MGB & SG & $\boldsymbol{p}$ \\
\hline \%EWL & $25,26 \pm 12,73$ & $25,10 \pm 8,37$ & 0,940 \\
\hline
\end{tabular}

\%EWL: (preoperatif kilo-güncel kilo) / (preoperatif kilo-ideal kilo)* 100

Tablo 3'de SG öncesi ve sonrası vücut kompozisyonlarının karşılaştırımasına ait sonuçlar görülmektedir. SG sonrası 1. ayda ortalama kilo 119,60 $\pm 22,81 \mathrm{~kg}$ 'dan 105,46 $\pm 20,68$ kg'a düşmüştür ve istatistiksel anlamlı bir farklılık saptanmıştır $(p=0,001)$. Aynı şekilde $S G$ sonrası 1. ayda VKi değerleri $44,62 \pm 6,68 \mathrm{~kg} / \mathrm{m}^{2}$ den $39,23 \pm 6,43 \mathrm{~kg} / \mathrm{m}^{2 \prime}$ ye düşmüştür ve istatistiksel anlamlı bir farklııı saptanmıştır $(p<0,001)$. SG sonrası 1. ayda üst ekstremite yağ kütlesi hem kadınlarda $(7,63 \pm 3,01 \mathrm{~kg}$ 'dan $5,86 \pm 2,21 \mathrm{~kg}$ 'a) hem de erkeklerde $(6,22 \pm 1,35 \mathrm{~kg}$ 'dan $3,92 \pm 1,11$ kg'a) anlamlı şekilde azalmıştır ( $p=0,002$; $p<0,001$ sırasıyla). Kadınlarda alt ekstremite ve gövde yağ kütlesi anlamlı şekilde azalırken $(p=0,004, \quad p=0,039$ sırasıly) erkeklerin alt ekstremite ve gövde yağ kütlesindeki azalma istatistiksel anlamlı değildir $(p=0,175, p=0,154$ sırasıyla).

SG sonrası hem kadınlarda hem de erkeklerde üst ekstremite kas kütlesinde anlamlı şekilde azalma saptanırken ( $p=0,018, p=0,027)$, alt ekstremite ve gövde kas kütlesindeki azalma anlamlı değildir. Kadınlarda tüm vücut yağ kütlesinde anlamlı azalma saptanırken $(p=0,014)$ erkeklerdeki azalma istatistiksel anlamlı değildir $(p=0,129)$. Erkeklerin tüm vücut yağsız kütlesindeki azalma istatistiksel olarak anlamlı iken kadınlardaki tüm vücut yağsız kütlesindeki azalma anlamlı değildir $(p=0,029$, $p=0,117$ sırasıyla).

Tablo 4'te MGB sonrası preop ve 1. ay vücut kompozisyonlarının karşılaştırılmasına ait sonuçlar görülmektedir. MGB sonrası kilo kaybı ve VKI değişmlerinde istatistiksel anlamlı bir farklılık saptanmıştır $(p=0,013, \quad p=0,001$ sırasıyla). MGB sonrası 1 . ayda kadınlarda üst ekstremite ve gövde yağ kütlesinde anlamlı bir azalma saptanmıştır ( $p=0,044$, $p=0,015$ sırasıyla) fakat alt ekstremite yağ kütlesindeki azalma istatistiksel olarak anlamlı değildir $(p=0,194)$. Erkeklerde MGB sonrası 1. ayda üst ekstremite, alt ekstremite ve gövde yağ kütlesindeki azalma istatistiksel olarak anlamlı değildir ( $p=0,221, p=0,191, p=0,771$ sırasıyla). MGB sonrası hem kadınlarda hem de erkeklerde üst ekstremite, alt ekstremite ve gövde kas kütlesinde azalma saptanmıştır fakat istatistiksel olarak anlamlı değildir. Aynı şekilde kadın ve erkelerde tüm vücut yağ kütlesi ve tüm vücut yağsız kütledeki azalma istatistiksel olarak anlamlı değildir.

Tablo 5'te MGB ve SG ameliyatlarında preoperatif ve postoperatif 1 . ay sonrası vücut kompozisyonlarındaki \% fark karşılaştırıımasına ait sonuçlar görülmektedir. SG sonrası üst ve alt ekstremite yağ kütlesindeki \% fark MGB ye 


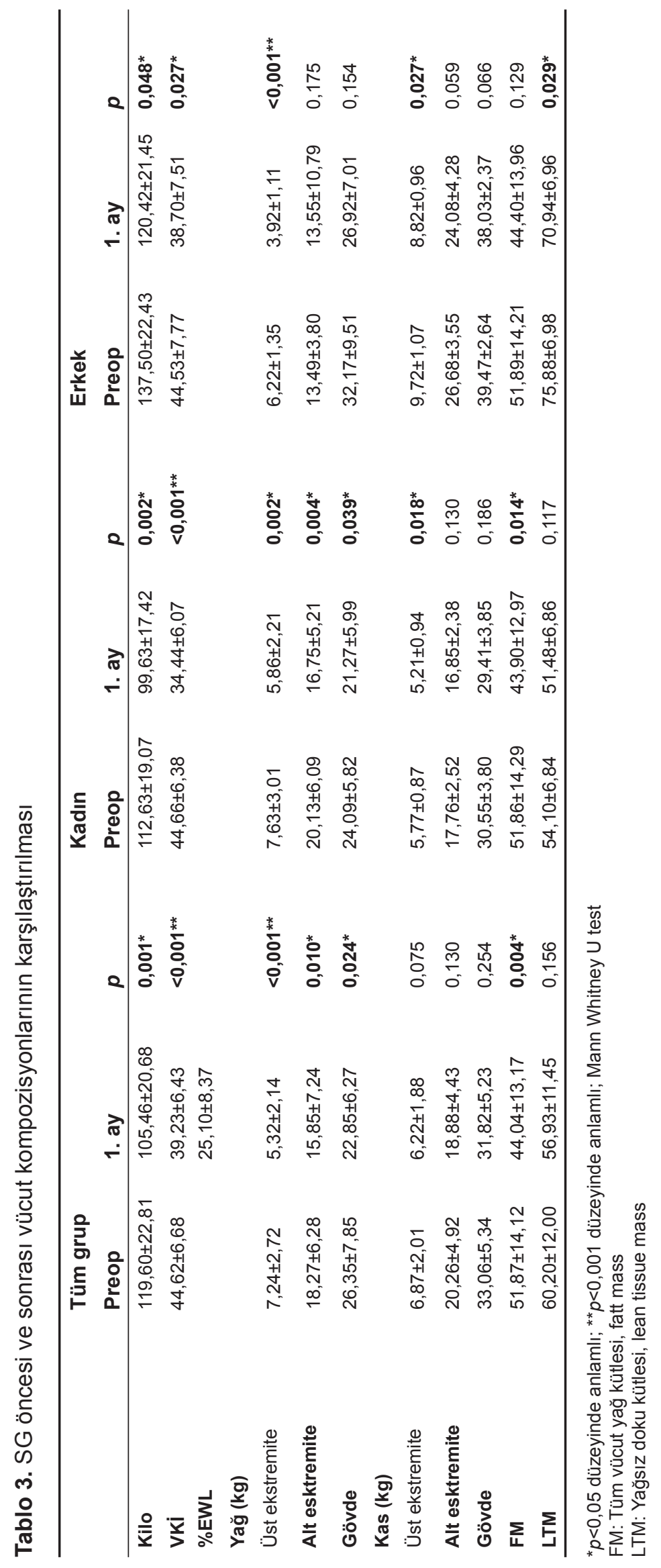




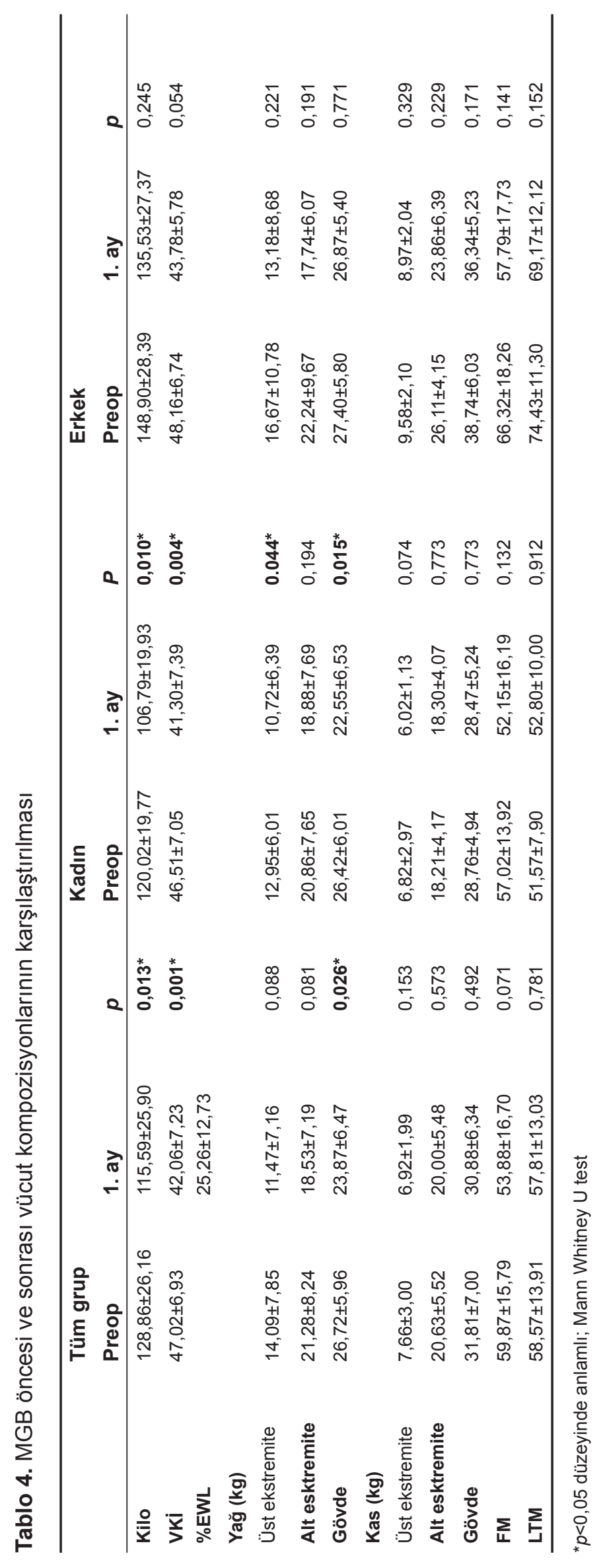




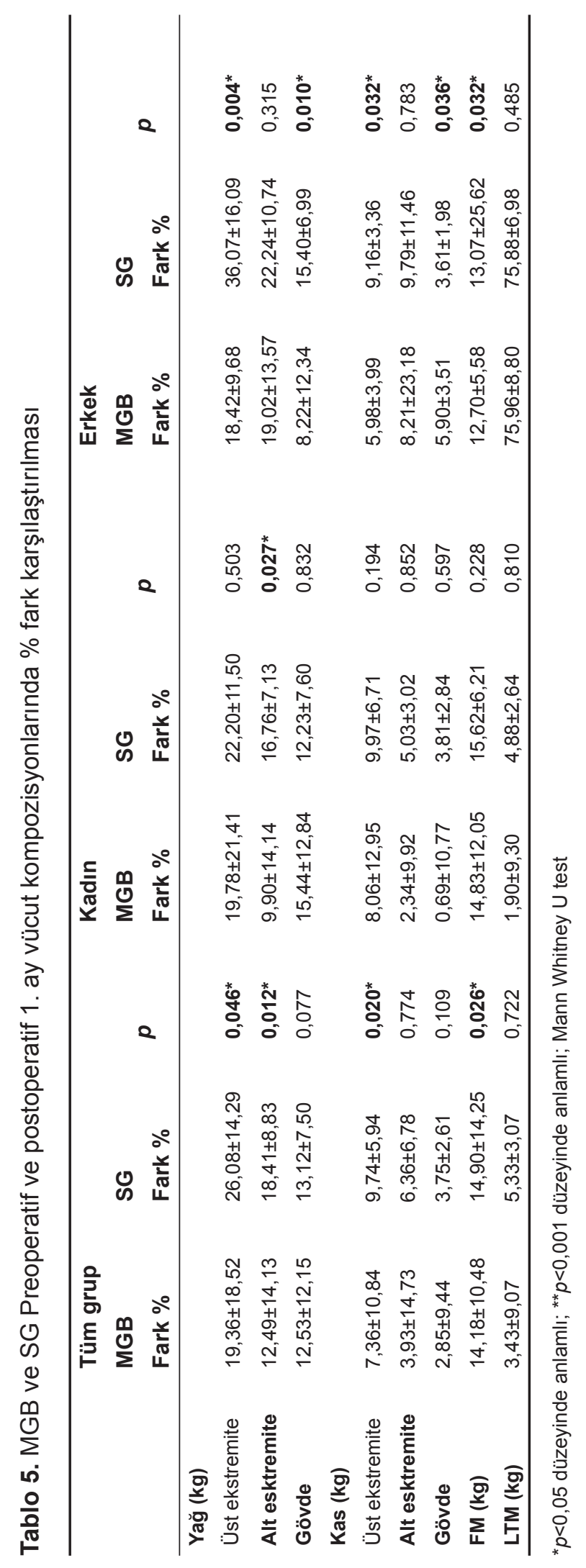


göre istatistiksel olarak anlamlı şekilde fazladır: ( $p=0,046, p=0,012$ sırasıyla). SG sonrası üst ekstremite kas kütlesi kaybı yüzdesi MGB ye göre anlamlı fazladır $(p=0,020)$. SG sonrası tüm vücut yağ kütle (FM) kaybı yüzdesi MGB ye göre anlamlı şekilde fazladır $(p=0,026)$. Kadınlarda SG sonrası MGB'ye göre alt ekstremite yağ kütle kaybı yüzdesi anlamlı ölçüde fazladır $(p=0,027)$. Erkeklerde SG sonrası MGB'ye göre üst ekstremite ve gövde yağ kütle kaybı yüzdesi anlamlı ölçüde fazladır ( $p=0,004, \quad p=0,010$ sırasıyla). Erkeklerde SG sonrası MGB'ye göre üst ekstremite kas kütle kaybı yüzdesi anlamlı ölçüde fazla iken $(p=0,032)$ MGB'de gövde kas kütle kaybı yüzdesi anlamlı ölçüde daha fazladır $(p=0,036)$. Erkeklerde $S G$ sonrası tüm vücut yağ kütle (FM) kaybı yüzdesi MGB'ye göre anlamlı ölçüde fazladır $(p=0,032)$.

\section{Tartışma}

Obezite ve ilişkili komorbiditeler sağlık alanında olduğu kadar global ekonomi açısından da son yıllarda karşımıza çıkan en önemli sorunlarından birini teşkil etmektedir $[20,21]$. Obezite ve tip 2 diyabet prevalansı hastalardaki beklenen yaşam süresini azaltmakla birlikte sağlık harcamalarını da önemli ölçüde arttırmaktadır [22, 23]. Obezite cerrahisi, obezite ve ilgili hastalıkları kalıcı olarak tedavi edebilen tek tedavi seçeneğidir $[24,25]$. Çeşitli obezite cerrahisi prosedürleri arasında RYGB ve slevee gastrektomi en sık kullanılan prosedürlerdir $[24,26]$. Restriktif ve malabsorptif yöntemler arasında RYGB kilo verme ve tip 2 diyabetin tedavisi açısından sleeve gastrektomiye göre daha iyi sonuçlar vermektedir [27, 28]. Ancak RYGB, sleeve gastrektomiye göre basitlik ve uygulanabilirlik açısından daha alt sıralarda kalmaktadır [29, 30]. Bu nedenle MGB, operasyon süresinin kısalığı, minimal perioperatif komplikasyon oranları, düşük mortalite oranları ve günlük yaşama hızlı geri dönüş oranlarını nedeniyle son zamanlarda artan oranda tercih edilen bariatrik prosedürdür haline gelmiştir [31].

BC'den 1 ay sonra akut kilo kaybının sadece vücut yağ kütlesi kaybından değil, aynı zamanda yağsız doku kütlesi kaybından da kaynaklandığını açıkça göstermektedir ve ayrıca vücut kompozisyonu değişikliğinin cinsiyet ve anatomik bölgeden etkilenebileceğini göstermiştir. MGB ve SG'den bir ay sonra, daha önce bildirilen verilerle uyumlu bir \% EWL bulduk
(\%25, 26 $\pm 12,73, \% 25,10 \pm 8,37$ sırasıyla) [32]. Bu veriler MGB ve SG sonrası akut kilo kaybını doğrular. Ayrıca çalışmamızda her iki cerrahi prosedür sonrası 1. ayda tüm vücut yağ kütlesi ve yağsız kütlede yaklaşık \%14 ile $\% 5$ civarında akut tüm vücut kompozisyonu değişikliği tespit ettik. Tüm vücut yağ kütle kaybı SG sonrasında daha fazladır. Fakat aynı şekilde yağsız doku kütlesi kaybı da SG sonrası MGB'ye göre daha fazladır. Bunun sebebi restriktif bir prosedür olan SG'de akut dönemde protein alımı yetersizliğine bağlı kas kaybı olabilceğini düşündük.

Çalışmamız, anatomik bölgeye göre LTM ve FMıdeki farklıııkları ayrıntılı olarak araştırmak için tasarlanmıştır. LTM ve FM'deki değişimleri anatomik bölgelere göre değişimlerini kıyasladık. Bu değişimlerin önemi, esas olarak gövdede ve karın bölgesinde biriken yağ dokunun metabolik ve kardiyovasküler sonuçları klinik öneme sahip olabilir. Çünkü gövde yağ kütlesi başlangıçta toplam FM'nin yarısından fazlasını temsil etmektedir [33].

Bizim çalışmamızda SG sonrası hem kadınlarda hem de erkeklerde LTM kaybı oluşmaktadır. Özellikle erkeklerde LTM kaybı kadınlara göre daha anlamlıdır. Anatomik bölgeye göre bakılacak olursa erkeklerde SG sonrası üst ektremitede kas kaybı ortaya çıkmaktadır. Kadınlarda da SG sonrası akut dönemde kas kaybı daha çok üst ekstremitede ortaya çıkmaktadır. LTM'deki azalma, postoperatif erken dönemde katı gıda alımında zorlanma, protein takviyesi ürünlerinin yetersiz kullanımı veya intolerasyonu nedeniyle oluşabilmektedir ve bu durum kas kütlesi katabolizmasına yol açabilmektedir [34].

MGB sonrası hem kadınlarda hem de erkeklerde FM ve LTM'de azalma görülmüştür ancak anlamlı değildir. Illginç bir şekilde tüm vücut anatomik bölgelerinde anlamlı kas kaybı oluşmamıştır. Bizim çalışmamızın sonuçlarına göre MGB sonrası akut dönemde kas kütle kaybının SG ye kıyasla daha az olmasının sebebi ise MGB'nin katı gıda ve protein alımına daha kolay adaptasyon sağladığı düşünülebilir. Toplam günlük kalori alımında ( 3 ayda $\% 75$ ) ve düşük protein alımında (3 ayda $\% 78,5)$ şiddetli azalma LTM kaybının ana sebepleridir [35].

Moize ve ark. [36] bariatrik cerrahi sonrası 4 ve 12 ay sonra en az $60 \mathrm{~g} / \mathrm{gün}$ veya $1,1 \mathrm{~g} / \mathrm{kg}$ ideal ağırlık/gün protein alımının, LTM'nin daha 
iyi korunması ile önemli ölçüde ilişkili olduğunu bildirmiştir. Sonuçlarımızda göze çarpan LTM kaybı akut dönemde meydana geldiğinden dolayı protein takviyesinin ilk aylardan itibaren önerilmesi gerekmektedir. Bu duruma paralel olarak son yıllarda yapılan çalışmalar postoperatif protein takviyesinin tüm vücut yağ kütlesinde azalmayı kolaylaştırdığını ve yağsız kütle kaybını azalttığını göstermiştir [37].

Çalışmamızın dikkat edilmesi gereken bazı kısıtlı yönleri mevcuttur. Özellikle kısıtlı hasta sayısı ve cinsiyet dağııımı orantısızdır. Kadınların oranı erkeklerden fazladır. Bunun sebebi ise kadınlarda morbid obezite ve bariatrik cerrahi başvuruları erkeklerden daha yüksektir. Ayrıca anatomik bölgelere göre kas ve yağ dağılımları değerlendirilmiştir fakat subkutan ve viseral yağ doku ölçümlerinin yapılmaması çalışmamızın kısıtlı yönlerinden biridir. Son olarak kan parametrelerinin, adipokinlerin ve obezite ile ilişkili hormonal değerlerin çalışmaya dahil edilmemesi çalışmamızın sınırlı olmasına sebep olmuştur. Daha fazla hasta sayısı ile en azından ideal kilo kaybına ulaşana dek postoperatif uzun takip sürelerini içeren çalışmalara intiyaç vardır.

Sonuçlarımız bariatrik cerrahinin akut kilo kaybına neden olduğunu ve hem tüm vücut yağ kütlesi hem de yağsız doku kütlesinin etkilendiğini ve bazı anatomik bölgelerde kas kaybının yağ kaybından daha yüksek olduğunu açıkça göstermektedir. Kas kütle kaybının uzun vadede zararlı sonuçları olabileceğinden, bariatrik cerrahi sonrası beslenme stratejilerinin mümkün olan en kısa sürede başlanması gerekliliğidir. Bariatrik cerrahi sonrası akut dönemde vücut kompozisyonundaki değişimlerin cinsiyet ve yapılan cerrahi prosedüre göre farklıııklar içerebileceği akılda tutulmalıdır.

Çıkar ilişkisi: Yazarlar çıkar ilişkisi olmadığını beyan eder.

\section{Kaynaklar}

1. Ng M, Fleming T, Robinson M, et al. Global, regional, and national prevalence of overweight and obesity in children and adults during 1980-2013: a systematic analysis for the Global Burden of Disease Study 2013. Lancet 2014;384:766-781. https://doi.org/10.1016/ S0140-6736(14)60460-8
2. Hales CM, Carroll MD, Fryar CD, Ogden CL. Prevalence of obesity and severe obesity among adults: United States, 2017-2018. 2020:8. Available at: https://www.cdc.gov/nchs/data/databriefs/db288.pdf. Accepted October 2017

3. Lancaster RT, Hutter MM. Bands and bypasses: 30-day morbidity and mortality of bariatric surgical procedures as assessed by prospective, multi-center, risk-adjusted ACS-NSQIP data. Surg Endosc 2008;22:2554-2563. https://doi.org/10.1007/s00464-008-0074-y

4. Kehagias I, Karamanakos SN, Argentou M, Kalfarentzos F. Randomized clinical trial of laparoscopic Roux-en-Y gastric bypass versus laparoscopic sleeve gastrectomy for the management of patients with $\mathrm{BMl}<50 \mathrm{~kg} / \mathrm{m} 2$. Obes Surg 2011;21:1650-1656. https:// doi.org/10.1007/s11695-011-0479-x

5. Sjöström L, Narbro K, Sjöström CD, et al. Effects of bariatric surgery on mortality in swedish obese subjects. N Engl J Med 2007;357:741-752. https://doi. org/10.1056/NEJMoa066254

6. Buchwald H, Ikramuddin S, Dorman RB, Schone JL, Dixon JB. Management of the metabolic/bariatric surgery patient. Am J Med 2011;124:1099-1105. https://doi.org/10.1016/j.amjmed.2011.05.035

7. Nocca D, Krawczykowsky D, Bomans B, et al. A prospective multicenter study of 163 sleeve gastrectomies: results at 1 and 2 years. Obes Surg 2008;18:560-565. https://doi.org/10.1007/s11695-0079288-7

8. Overs SE, Freeman RA, Zarshenas N, Walton KL, Jorgensen JO. Food tolerance and gastrointestinal quality of life following three bariatric procedures: adjustable gastric banding, Roux-en- $Y$ gastric bypass, and sleeve gastrectomy. Obes Surg 2012;22:536-543. https://doi.org/10.1007/s11695-011-0573-0

9. Dogan K, Gadiot RPM, Aarts EO, et al. Effectiveness and safety of sleeve gastrectomy, gastric bypass, and adjustable gastric banding in morbidly obese patients: a multicenter, retrospective, matched cohort study. Obes Surg 2015;25:1110-1118. https://doi.org/10.1007/ s11695-014-1503-8

10. Georgiadou D, Sergentanis TN, Nixon A, Diamantis T, Tsigris C, Psaltopoulou T. Efficacy and safety of laparoscopic mini gastric bypass. A systematic review. Surg Obes Relat Dis 2014;10:984-991. https://doi. org/10.1016/j.soard.2014.02.009

11. Noria SF, Grantcharov T. Biological effects of bariatric surgery on obesity-related comorbidities. Can J Surg 2013;56:47-57. https://doi.org/10.1503/cjs.036111

12. Mahawar KK, Carr WRJ, Balupuri S, Small PK. Controversy surrounding "mini" gastric bypass. Obes Surg 2014;24:324-333. https://doi.org/10.1007/ s11695-013-1090-0 
13. Mahawar KK, Jennings N, Brown J, Gupta A, Balupuri S, Small PK. "Mini" gastric bypass: systematic review of a controversial procedure. Obes Surg 2013;23:18901898. https://doi.org/10.1007/s11695-013-1026-8

14. Freedman DS, Khan LK, Serdula MK, Galuska DA, Dietz WH. Trends and correlates of class 3 obesity in the United States from 1990 through 2000. JAMA 2002;288:1758-1761. https://doi.org/10.1001/ jama.288.14.1758

15. Suter M, Giusti V. [Surgical options for obesity: results and complications]. Rev Med Suisse 2005;1:832-836.

16. Schiavo L, Scalera G, Pilone V, et al. A comparative study examining the impact of a protein-enriched vs normal protein postoperative diet on body composition and resting metabolic rate in obese patients after sleeve gastrectomy. Obes Surg 2017;27:881-888. https://doi.org/10.1007/s11695-016-2382-y

17. Albanopoulos K, Tsamis D, Natoudi M, Alevizos L, Zografos G, Leandros E. The impact of laparoscopic sleeve gastrectomy on weight loss and obesityassociated comorbidities: the results of 3 years of follow-up. Surg Endosc 2016;30:699-705. https://doi. org/10.1007/s00464-015-4262-2

18. de Aquino LA, Pereira SE, de Souza Silva J, Sobrinho CJS, Ramalho A. Bariatric surgery: impact on body composition after Roux-en-Y gastric bypass. Obes Surg 2012;22:195-200. https://doi.org/10.1007/ s11695-011-0500-4

19. Maïmoun L, Lefebvre $P$, Jaussent A, Fouillade C, Mariano-Goulart D, Nocca D. Body composition changes in the first month after sleeve gastrectomy based on gender and anatomic site. Surg Obes Relat Dis 2017;13:780-787. https://doi.org/10.1016/j. soard.2017.01.017

20. Danaei G, Finucane MM, Lu Y, et al. National, regional, and global trends in fasting plasma glucose and diabetes prevalence since 1980: systematic analysis of health examination surveys and epidemiological studies with 370 country-years and $2 \cdot 7$ million participants. Lancet 2011;378:31-40. https://doi. org/10.1016/S0140-6736(11)60679-X

21. Ogden CL, Carroll MD, Kit BK, Flegal KM. Prevalence of obesity among adults: United States, 2011-2012. NCHS Data Brief 2013:1-8.

22. Fontaine $K R$, Redden $D T$, Wang $C$, Westfall $A O$, Allison DB. Years of life lost due to obesity. JAMA2003;289:187193. https://doi.org/10.1001/jama.289.2.187

23. Abegunde DO, Mathers CD, Adam T, Ortegon M, Strong K. The burden and costs of chronic diseases in low-income and middle-income countries. Lancet 2007;370:1929-1938. https://doi.org/10.1016/S01406736(07)61696-1

24. Buchwald $\mathrm{H}$, Avidor $\mathrm{Y}$, Braunwald $\mathrm{E}$, et al. Bariatric surgery: a systematic review and meta-analysis. JAMA 2004;292:1724-1737. https://doi.org/10.1001/ jama.292.14.1724
25. Schauer PR, Bhatt DL, Kirwan JP, et al. Bariatric surgery versus intensive medical therapy for diabetes-3-year outcomes. N Engl J Med 2014;370:2002-2013. https://doi.org/10.1056/NEJMoa1401329

26. Maggard MA, Shugarman LR, Suttorp M, et al. Metaanalysis: surgical treatment of obesity. Ann Intern Med 2005;142:547-559. https://doi.org/10.7326/0003-4819142-7-200504050-00013

27. Lee WJ, Chong K, Ser KH, et al. Gastric bypass vs sleeve gastrectomy for type 2 diabetes mellitus: a randomized controlled trial. Arch Surg 2011;146:143148. https://doi.org/10.1001/archsurg.2010.326

28. Li J, Lai D, Wu D. Laparoscopic Roux-en-Y gastric bypass versus laparoscopic sleeve gastrectomy to treat morbid obesity-related comorbidities: a systematic review and meta-analysis. Obes Surg 2016;26:429442. https://doi.org/10.1007/s11695-015-1996-9

29. Albeladi B, Bourbao Tournois C, Huten N. Short and midterm results between laparoscopic Roux-en-Y gastric bypass and laparoscopic sleeve gastrectomy for the treatment of morbid obesity. J Obes 2013;2013:1-6. https://doi.org/10.1155/2013/934653

30. Rubino F, Forgione A, Cummings DE, et al. The mechanism of diabetes control after gastrointestinal bypass surgery reveals a role of the proximal small intestine in the pathophysiology of type 2 diabetes. Ann Surg 2006;244:741-749. https://doi.org/10.1097/01. sla.0000224726.61448.1b

31. Musella M, Milone M. Still "controversies" about the mini gastric bypass? Obes Surg 2014;24:643-644. https://doi.org/10.1007/s11695-014-1193-2

32. Mostafa EA, Wahab EMA, Sayed YGA, Gafar MH. Laparoscopic sleeve gastrectomy versus laparoscopic minigastric bypass in management of morbid obesity and its comorbidities. Menoufia Med J 2018;31:18811186. Available at: http://www.mmj.eg.net/temp/Men oufiaMedJ3141181-3797514_103255.pdf. Accepted August 28, 2018

33. Després J P, Lemieux I. Abdominal obesity and metabolic syndrome. Nature 2006;444:881-887. https://doi.org/10.1038/nature05488

34. Friedrich AE, Damms Machado A, Meile T, et al. Laparoscopic sleeve gastrectomy compared to a multidisciplinary weight loss program for obesity-effects on body composition and protein status. Obes Surg 2013;23:1957-1965. https://doi.org/10.1007/ s11695-013-1036-6

35. Belfiore A, Cataldi M, Minichini L, et al. Short-Term changes in body composition and response to micronutrient supplementation after laparoscopic sleeve gastrectomy. Obes Surg 2015;25:2344-2351. https://doi.org/10.1007/s11695-015-1700-0

36. Moizé V, Andreu A, Rodríguez L, et al. Protein intake and lean tissue mass retention following bariatric surgery. Clin Nutr 2013;32:550-555. https://doi. org/10.1016/j.clnu.2012.11.007 
37. Schollenberger AE, Karschin J, Meile $T$, Küper MA, Königsrainer A, Bischoff SC. Impact of protein supplementation after bariatric surgery: a randomized controlled double-blind pilot study. Nutrition 2016;32:186-192. https://doi.org/10.1016/j. nut.2015.08.005

Etik kurul onayı: Pamukkale Üniversitesi Tıp Fakültesi Girişimsel Olmayan Klinik Araştırmalar Etik Kurulu'ndan onay alındı (60116787-020 / 29694).

\section{Yazarların makaleye olan katkıları}

ve $\begin{array}{ccc}\text { M.A. çalışmanın } \\ \text { hipotezini }\end{array}$ M.R.A. materyal metod bölümünü düzenlemiştir. S.Y. verilerin değerlendirmesi ve istatistiksel analizlerini yapmıştır. Makalenin tartışma bölümü M.R.A. tarafından yazılmıştır. M.A. makalenin gerekli düzenlemelerini yapmıştır. Tüm yazarlar çalışmanın tamamını tartışmış ve son halini onaylamışlardır. 